\title{
Review
}

\section{Next-Generation Gene Therapy for Parkinson's Disease Using Engineered Viral Vectors}

\author{
Tomas Björklund* and Marcus Davidsson \\ Molecular Neuromodulation, Wallenberg Neuroscience Center, Lund University, Lund, Sweden
}

Accepted 14 July 2021

Pre-press 3 August 2021

\begin{abstract}
Recent technological and conceptual advances have resulted in a plethora of exciting novel engineered adeno associated viral (AAV) vector variants. They all have unique characteristics and abilities. This review summarizes the development and their potential in treating Parkinson's disease (PD). Clinical trials in PD have shown over the last decade that AAV is a safe and suitable vector for gene therapy but that it also is a vehicle that can benefit significantly from improvement in specificity and potency. This review provides a concise collection of the state-of-the-art for synthetic capsids and their utility in PD. We also summarize what therapeutical strategies may become feasible with novel engineered vectors, including genome editing and neuronal rejuvenation.
\end{abstract}

Keywords: Genetic therapy, Parkinson's disease, clinical trial, gene editing, rejuvenation, neuroprotection, dependovirus

Viral vector technology for the treatment of Parkinson's disease (PD) has undergone three significant generations of improvement over the last two decades. What was initially ex vivo gene transfer using retroviral vectors was developed into proofof-concept in vivo gene expression using adenoviral, herpes simplex (HSV), or lentiviral vectors [1]. One lentiviral vector has even reached clinical trials for enzyme replacement in PD [2]. However, a significant breakthrough was seen with the application of adenoassociated viral (AAV) vectors for gene therapy in the CNS [3]. The AAV virus has a few unique features, making it a near-instant success as the clinical gene therapy vector of choice in non-dividing cells. As a dependovirus (i.e., requiring Adenovirus or HSV

\footnotetext{
${ }^{*}$ Correspondence to: Tomas Björklund, Molecular Neuromodulation, Wallenberg Neuroscience Center, Lund University, BMC A10, 22184 Lund, Sweden. E-mail: tomas.bjorklund@med.lu.se.
}

co-infection for replication), it had already outsourced an intricate component of the replication process to other viruses [4]. These mechanisms could, fortunately, be replaced by transient transfection of plasmids in the production cell line. This approach left the need for only two major genes (and two minor genes expressed from the same genetic sequence) to be expressed from the AAV genome. They are required for viral genome replication and packaging (the replication gene Rep) and viral capsid synthesis (the Cap gene).

Like the helper-genes derived from the Adenovirus, the Rep and Cap genes could be extracted from the AAV genome and placed in a third plasmid during production. The resulting transient transfection system produces a replication-deficient, gutted AAV vector where only the inverted terminal repeats (ITRs) remain in the viral vector's genome [4]. For a more complete picture of AAV biology and AAV life cycle see Vance et al. (2015) [5]. 
The space generated from removing the Rep and Cap genes (between the ITRs) is filled with the therapeutic gene of choice, including promoter and required regulatory sequences for mRNA stability. To date, AAV vectors have been utilized in 241 clinical trials (planned, ongoing, and performed, clinicaltrials.gov), including trials in PD (15 trials), and over 10,000 patients have received the vector (over 400 in PD). So far, only three AAV-based therapies have reached approval, two in the US and Europe and the third only in Europe. While encouraging, the progress has not been clear cut and many therapies have failed or reached a standstill at different stages of preclinical [6] and clinical testing [7, 8]. However, clinical trials are still being evaluated for the AAV-mediated AADC pro-drug approach, both in PD [9] and in children with AADC insufficiency (NCT02852213) and GDNF neuroprotection, in PD and multiple system atrophy (NCT01621581 \& NCT04680065 at clinicaltrials.gov).

Although the AAV capsid and the gutted genome remain one of the lowest immunogenic gene therapy vectors developed to date, it is not without risks of complications [10]. Most patients have neutralizing antibodies against one AAV serotype or another. The common AAV seropositivity has two significant implications [10]. The primary implication is that not all patients are equally suitable for a particular AAV-based therapy, and a considerable fraction of the patient cohort may have to be excluded. The second implication is that this shows that our immune system reacts to the AAV infection and can develop strong immunity against the AAV capsid [11]. Thus, we need to monitor immune reactions carefully and not expect a therapeutic vector to be re-administered in the same patient without modifications. Circulating anti-AAV antibodies have not been extensively reported in the clinical trials using AAV for PD, but some data have been reported in the context of the AAV2 based GAD Phase I Trial (NCT00195143) [8]. In this trial seven out of twelve patients showed detectable levels of anti-AAV antibodies with two patients showing very high levels. This did not negatively impact the safety profile of the therapy, but it is still unknown if it had any impact on the transduction efficacy. A preclinical study suggests that circulating anti-AAV antibodies may not be the sole determinant to inhibit brain transduction [12].

Fortunately, genetic engineering provides new avenues to address these issues and has the potential to revolutionize the gene therapy field, not least in PD [13].

\section{METHODOLOGIES TO ENGINEER THE CAPSID SURFACE}

Genetic engineering, economical and accurate multiplexed gene synthesis [14], deep sequencing, and rapid production techniques [15] have opened up an entirely new avenue for AAV engineering. In a single round of in vivo screening, we can perform experiments that previously required years of directed evolution and iterative improvements [16].

With the new generation of AAV evolution, the capsid surface regions responsible for cell adhesion and infectivity can be accurately tailored for cell-type specificity or novel functional properties (Table 1). Such properties can be to traffic across the bloodbrain barrier (BBB) [17] or transport retrogradely in axons $[16,18]$. However, capsid engineering does not have to be limited to tropism or transport. The same approach can be taken to systematically modify each amino acid over the entire capsid and thereby potentially allow for the identification of immune-evading variants or capsid variants with increased packaging capacity (a significant limitation with wild-type AAV variants) [14]. However, increased packaging capacity may come with altered transduction efficiency and infectivity profiles, and further work is needed to answer these questions.

One AAV-evolution approach has led to the PHP.B/eB AAV variant, which show highly efficient transport over the BBB in C57/BL6 mice [17, 19, 20] (Fig. 1). While being a very useful research tool, it lacks clinical applications using systemic injections because it depends on the Ly6A receptor expression, which is not found in higher species (e.g., rats and primates) and is also absent in many other mouse strains [21]. However, recent publications utilizing PHP.B/eB have showed efficient transduction in the $\mathrm{CNS}$ in rats and nonhuman primates (NHP) following intrathecal injections [22, 23]. Due to this unfortunate revelation, the search is still on to find an equally potent capsid variant for systemic injections, suitable for clinical translation [24-28]. A promising development is the TRACER 9P801 capsid developed by Voyager therapeutic. At the time of completion of this review, this capsid was only presented at the American Society for Cell and Gene therapy meeting but shows significant improvement in BBB crossing and CNS transduction in the NHP [29].

We have taken a different approach in the BRAVE (Barcoded Rational AAV Vector Evolution) methodology of capsid engineering [16]. With this approach, we computationally devise novel capsid variants 
Table 1

Novel AAV capsid variants to keep an eye on for research and clinical therapies in PD

\begin{tabular}{|c|c|c|c|c|c|c|c|c|c|}
\hline Methodology & Capsid & Origin & Transduction target & Injection & $\begin{array}{l}\text { Species used for } \\
\text { screening }\end{array}$ & Other species tested & Noteworthy characteristics & Ref & Year \\
\hline BRAVE & MNM008 & AAV2 & $\begin{array}{l}\text { Retrograde infectivity of } \\
\text { DA neurons }\end{array}$ & Direct & Sprague Dawley rats & Humanized rat & $\begin{array}{l}\text { Retrograde transport to human DA } \\
\text { neurons in vivo }\end{array}$ & [16] & 2019 \\
\hline BRAVE & MNM004 & AAV2 & $\begin{array}{l}\text { Retrograde infectivity of } \\
\text { neurons }\end{array}$ & Direct & Sprague Dawley rats & Humanized rat & $\begin{array}{l}\text { Similar retrograde efficiency as } \\
\text { AAV2-Retro }\end{array}$ & [16] & 2019 \\
\hline TRACER & 9P31 & AAV9 & $\begin{array}{l}\text { Neurons, spinal cord \& } \\
\text { heart }\end{array}$ & IV & $\mathrm{C} 56 \mathrm{~B} 1 / 6 \mathrm{~J} \& \mathrm{BALB} / \mathrm{c}$ mice & - & - & {$[27]$} & 2020 \\
\hline TRACER & 9P801 & AAV9 & Neurons, spinal cord & IV & NHP & - & Identified from screening in NHP & [29] & 2021 \\
\hline iTransduce & AAV-F & AAV9 & $\begin{array}{l}\text { Neurons, spinal cord \& } \\
\text { astrocytes }\end{array}$ & IV & $\begin{array}{l}\mathrm{C} 57 \mathrm{Bl} / 6 \mathrm{~J} \text { and } \mathrm{BALB} / \mathrm{c} \\
\text { mice }\end{array}$ & - & $\begin{array}{l}\text { Fetal-derived primary human } \\
\text { neurons }\end{array}$ & [26] & 2019 \\
\hline iTransduce & AAV-S & AAV9 & $\begin{array}{l}\text { Neurons, astrocytes \& } \\
\text { muscle }\end{array}$ & IV & $\begin{array}{l}\mathrm{C} 57 \mathrm{Bl} / 6 \mathrm{~J} \text { and } \mathrm{BALB} / \mathrm{c} \\
\text { mice }\end{array}$ & - & Peripheral organs & [26] & 2019 \\
\hline SCHEMA & $\mathrm{SCH} 9$ & AAV9 & CNS, NSCs in the SVZ & Direct & $\begin{array}{l}\text { C57B1/6J, Cre \& } \\
\text { tdTomato mice }\end{array}$ & - & $\begin{array}{l}\text { Efficiently transduces Purkinje } \\
\text { Cells }\end{array}$ & {$[28]$} & 2018 \\
\hline M-CREATE & CAP-B10 & AAV9 & CNS - neurons & IV & C57B1/6J \& Cre mice & Marmosets & Peripheral detartgeting & [24] & 2020 \\
\hline M-CREATE & CAP-B22 & AAV9 & CNS - broad transduction & IV & C57B1/6J \& Cre mice & Marmosets & - & [24] & 2020 \\
\hline M-CREATE & PHP.V1 & AAV9 & Brain vascular cells & IV & C57Bl/6J \& Cre mice & - & $\begin{array}{l}\text { Astrocytes (less efficient than } \\
\text { PHP.eB) }\end{array}$ & {$[25]$} & 2020 \\
\hline CREATE & PHP.eB & AAV9 & Neurons \& astrocytes & IV & $\mathrm{C} 57 / \mathrm{B} 16 \mathrm{~J}$ mice & $\mathrm{BALB} / \mathrm{cJ} \& \mathrm{NHP}$ & Limited to C57BL/6J mice & [19] & 2017 \\
\hline CREATE & PHP.S & AAV9 & $\begin{array}{l}\text { DRG, cardiac \& enteric } \\
\text { neurons }\end{array}$ & IV & C57/B16J mice & - & Liver, lung, heart stomach & [19] & 2017 \\
\hline Directed evolution & AAV2-retro & AAV2 & $\begin{array}{l}\text { Retrograde infectivity of } \\
\text { neurons }\end{array}$ & Direct & $\mathrm{C} 57 / \mathrm{B} 16 \mathrm{~J}$ mice & Macaque \& rats & $\begin{array}{l}\text { Efficient retrograde transport (not } \\
\text { DA neurons) }\end{array}$ & [18] & 2016 \\
\hline Rational design & AAV9-retro & AAV9 & Neurons & IV \& direct & C57/B16J mice & - & $\begin{array}{l}\text { Similar retrograde efficiency to } \\
\text { AAV2-Retro }\end{array}$ & [59] & 2020 \\
\hline Rational design & $\mathrm{T} 23 \mathrm{Y}+\mathrm{T}+\mathrm{dH}$ & AAV2 & Neurons & Direct & Sprague Dawley rats & - & Increased transduction volume & {$[60]$} & 2017 \\
\hline Rational design & AAV-TT & AAV2 & Neurons & Direct & SD rats & $\mathrm{C} 57 \mathrm{Bl} / 6 \mathrm{~J}$ & $\begin{array}{l}\text { Transduces photoreceptors and } \\
\text { astrocytes }\end{array}$ & {$[61]$} & 2018 \\
\hline Rational design & AAV8 THR & AAV8 & Neurons \& Periphery & IV & C57/B16J mice & - & $\begin{array}{l}\text { Decreased clearance with THR } \\
\text { binding }\end{array}$ & {$[62]$} & 2018 \\
\hline Rational design & AAV2.5 & AAV2 & Muscle cells & IM & $\mathrm{BALB} / \mathrm{c}$ mice & Human & The only one used in a clinical trial & [63] & 2012 \\
\hline DNA shuffling & AAV-DJ & AAV2/8/9 & $\begin{array}{l}\text { Liver (and CNS after direct } \\
\text { injection) }\end{array}$ & IV & FWB mice & C57BL/6J & In vitro infectivity & [64] & 2008 \\
\hline DNA shuffling & AAV-B1 & Numerous & $\begin{array}{l}\text { CNS, skeletal muscle \& } \\
\text { heart }\end{array}$ & IV & $\mathrm{C} 57 \mathrm{~B} 1 / 6 \mathrm{~J}$ & Cat & Efficient in pancreas and lung & {$[65]$} & 2016 \\
\hline Peptide insertion & AAV-AS & AAV9 & CNS - neurons & IV & $\mathrm{C} 57 \mathrm{~B} 1 / 6 \mathrm{~J}$ & Cat & Spinal cord & {$[66]$} & 2016 \\
\hline
\end{tabular}




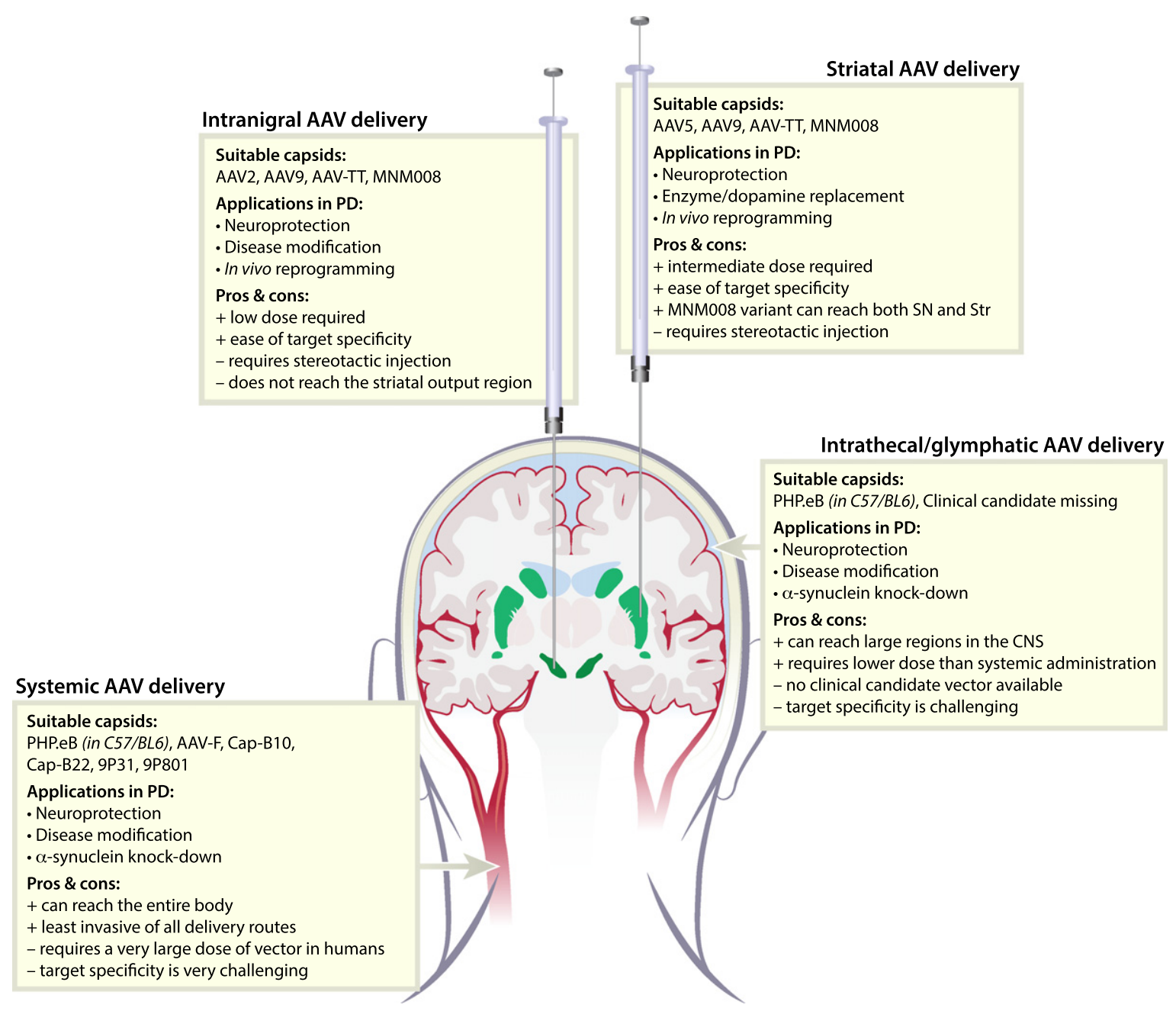

Fig. 1. Delivery routes and suitable AAV variants for gene therapy in Parkinson's disease. To target the basal ganglia, AAV vectors can be delivered through four different routes; Intranigral, striatal, intrathecal, or systemic. All routes have advantages but also present challenges. Fortunately, we now have engineered AAV-vector capsids suitable for most routes.

inspired by other viral proteins or endogenous proteins/ligands with desired functions such as cell type tropism or transportation characteristics. With this approach, we can be sure that the protein sequence selected will be efficiently synthesized in human cells, and the potential for being infective crossspecies is increased. The same library can then be characterized across numerous model systems such as hESC-derived dopamine (DA) cells, organoids, transplanted human neurons in the rat brain, and many more $[30,31]$. The readout from each model system can then be integrated to identify novel capsid variants to be highly efficient and translational to the human brain.

With this approach, we have generated (among many others) the MNM008 AAV capsid variant with a unique capacity to reach DA neurons from the terminals (Fig. 1). However, the potential of the system does not stop there. It has the potential to allow us to identify capsid variants that could potentially traffic from the glymphatic system (through the intrathecal delivery route) [32] or over the BBB (after i.v. injection) [33] and home to the DA neurons. Thanks to the novel multiplexed gene synthesis approaches, such improvements can be made iteratively and systematically.

However, making such improvements will also require advancement in our ability to predict function and extrapolate from large sets of data. This is where recent advances in machine learning (ML) and machine-guided design can prove to be essential. In an initial exploration, ML has been applied to predict 
capsid assembly with training data generated from AAV libraries [34]. In a very recent study by Bryant et al., ML has been used to construct AAV variants that can differ significantly from any known AAV serotype without losing the capacity to assemble and infect [35]. One area where such large changes are essential is immune evasion.

\section{AVOIDANCE OF INNATE IMMUNE RESPONSES}

The adaptive immune system with preexisting neutralizing antibodies and recruitment of capsidspecific cytotoxic T cells is only one hurdle for administration or re-administration of AAVs. Furthermore, studies also show varying levels of neutralizing antibodies to different serotypes, both in humans and NHP [12, 36].

More work on how AAVs can evade circulating antibodies is needed. However, several studies have addressed the question successfully and provided valuable information on the subject [37, 38].

The innate immune system can also recognize the AAV infectivity by triggering the Toll-like receptor 9 (TLR9) mediated by the AAV genome. Chan et al., have recently shown an exciting proof-of-concept for incorporating TLR9 inhibition into the therapeutic AAV genome itself [39]. This is achieved by using a short repeat structure inspired by mammalian telomeres with the motif TTAGGG. This small change alone was observed to significantly reduce the innate immune activation in both mice and pigs but with a smaller effect in NHP. While requiring further improvements before being clinically relevant it provides important insights into AAV immunity.

\section{ENGINEERING THE AAV GENOME FOR TARGET SPECIFICITY}

The engineering of the AAV capsid holds great promise for improving gene therapy efficacy in PD. Still, it will not be able to achieve every goal of specificity and regulation. Not every cell type or cell state will have an external representation on the cell surface which may be permissive to AAV targeting. Furthermore, as AAV-based gene therapy is irreversible in its current form, there are many scenarios where a regulated therapeutic approach is modulated, e.g., by inflammation state or apoptotic cascade.

Earlier attempts have focused on the inclusion of cell-type-specific promoters into the AAV-genome to drive the transgene expression. However, taking the promotor out of its genomic context and truncating it to fit the limited space of the AAV has led to disappointing results [40]. Specificity is usually low and unpredictable and can even change dramatically, e.g., from glial cells to dopamine neurons [41].

A promising alternative avenue is to incorporate short enhancer sequences upstream of minimal promoters. Recent advances in the sequencing of chromatin accessibility in bulk tissue and single nuclei have enabled us to accurately identify short enhancer elements with high cell-type and cell state specificity [42, 43]. Importantly, this mapping can be achieved at single-nuclei resolution also from human post-mortem brain samples [44]. The identified enhancer elements have been used to generate AAV genomes with high specificity for cortical neuronal subtypes [45]. It is highly conceivable that a similar approach can be taken to identify enhancer elements relevant to PD. Such vectors could sense both relevant dopamine neuron subtypes and disease state and only express the therapeutic transgene in the right cell at the right time and at a physiological dose. A major challenge will be translatability as chromatin state and enhancer function are not guaranteed across species and disease states. Humanized animals, accurate disease models, and efficient screening techniques will here be instrumental.

In scenarios where it is not feasible to restrict the therapeutic transgene expression through capsid or promoter engineering, improvements in delivery may provide improved target specificity instead. One such approach is targeted ultrasound where the BBB is transiently opened in a confined region of the brain to allow for passage of the AAV from the blood stream $[46,47]$.

\section{TOWARDS CLINICAL UTILITY IN PD}

To date, very few engineered AAV have been utilized in the clinic [48] but many are now on the horizon. AAV engineering has the potential to radically improve the on-target specificity and thereby reduce the dose needed and the immune response. The CRISPR toolbox is evolving at a very rapid pace, with exciting tools for gene perturbation arising. One such development is the CasRx RNAguided RNA nuclease [49]. What this system allows for is the possibility for gene perturbations at the RNA level without the modification of the genome or the formation of unpredictable protein variants 
formed by NHEJ (non-homologous end-joining). CRISPR perturbation has been shown to have a much higher on-target specificity than previously used shRNA/microRNA-based RNA-interference [49], which further strengthens its translational appeal. Recently, Zhou et al., achieved in vivo reprogramming of resident striatal glia into functional dopamine neurons through the CasRx mediated silencing of the PTB gene [50]. If this is reproduced in other modeling systems, it has intriguing potential.

Another area in clinical translation where engineered AAV vectors have great potential is in combination with cell therapy utilizing extrinsic cell sources such as ESCs or IPS cells. AAV vectors have the potential to facilitate accurate modulation of DA graft function to potentiate the therapeutic outcome [51], modulate any potential adverse events [52] and tailor the cells to avoid immune rejection [53]. In a future where autologous cell sources have become a reality (being it from in vivo reprogramming or transplantation), an important application of viral vectors is to correct any disease-causing gene changes (e.g., a-synuclein overexpression) in the host's cells [54].

Further in the future, engineered AAVs may become so safe, targeted, and efficient that we can start to explore them for neuroprotection and disease prevention in broader masses, even in pre-symptomatic PD or in people with increased risk of developing PD. While very early days, such therapies could target macroautophagy [55], slow down neuronal aging $[56,57]$ or even rejuvenate the dopamine neurons [58].

\section{CONCLUDING REMARKS}

Technological advances have had a remarkable impact on the AAV capsid development. The bar has been raised for what is possible to achieve using viral vector-based gene therapy, not least in the CNS. Engineered AAVs and genome editing are a perfect match for novel clinical therapies. We expect that we will see some of the herein presented capsids moving to the clinic for multiple indications, not least PD. While a challenging road ahead, the future is bright for gene therapy, and we will see many more capsids emerging with even greater potential.

\section{CONFLICT OF INTEREST}

MD and TB are inventors of multiple patents related to gene therapy. MD and TB are founders and directors of Brave Bioscience AB. TB is a co-founder and SAB member of Dyno Therapeutics.

\section{REFERENCES}

[1] Bjorklund T, Kordower JH (2010) Gene therapy for Parkinson's disease. Mov Disord 25(Suppl 1), S161-173.

[2] Palfi S, Gurruchaga JM, Lepetit H, Howard K, Ralph GS, Mason S, Gouello G, Domenech P, Buttery PC, Hantraye P, Tuckwell NJ, Barker RA, Mitrophanous KA (2018) Longterm follow-up of a Phase I/II study of ProSavin, a lentiviral vector gene therapy for Parkinson's disease. Hum Gene Ther Clin Dev 29, 148-155.

[3] Li C, Samulski RJ (2020) Engineering adeno-associated virus vectors for gene therapy. Nat Rev Genet 21, 255-272.

[4] Wu Z, Asokan A, Samulski RJ (2006) Adeno-associated virus serotypes: Vector toolkit for human gene therapy. Mol Ther 14, 316-327.

[5] Vance MA, Mitchell A, Samulski RJ (2015) AAV biology, infectivity and therapeutic use from bench to clinic. In Gene Therapy - Principles and Challenges, Hashad D, ed. InTech.

[6] Rosenblad C, Li Q, Pioli EY, Dovero S, Antunes AS, Agundez L, Bardelli M, Linden RM, Henckaerts E, Bjorklund A, Bezard E, Bjorklund T (2019) Vectormediated 1-3,4-dihydroxyphenylalanine delivery reverses motor impairments in a primate model of Parkinson's disease. Brain 142, 2402-2416.

[7] Marks WJ, Jr., Ostrem JL, Verhagen L, Starr PA, Larson PS, Bakay RA, Taylor R, Cahn-Weiner DA, Stoessl AJ, Olanow CW, Bartus RT (2008) Safety and tolerability of intraputaminal delivery of CERE-120 (adeno-associated virus serotype 2-neurturin) to patients with idiopathic Parkinson's disease: An open-label, phase I trial. Lancet Neurol 7, 400-408.

[8] Kaplitt MG, Feigin A, Tang C, Fitzsimons HL, Mattis P, Lawlor PA, Bland RJ, Young D, Strybing K, Eidelberg D, During MJ (2007) Safety and tolerability of gene therapy with an adeno-associated virus (AAV) borne GAD gene for Parkinson's disease: An open label, phase I trial. Lancet 369, 2097-2105.

[9] Nutt JG, Curtze C, Hiller A, Anderson S, Larson PS, Van Laar AD, Richardson RM, Thompson ME, Sedkov A, Leinonen M, Ravina B, Bankiewicz KS, Christine CW (2020) Aromatic L-amino acid decarboxylase gene therapy enhances Levodopa response in Parkinson's disease. Mov Disord 35, 851-858.

[10] Verdera HC, Kuranda K, Mingozzi F (2020) AAV vector immunogenicity in humans: A long journey to successful gene transfer. Mol Ther 28, 723-746.

[11] Barnes C, Scheideler O, Schaffer D (2019) Engineering the AAV capsid to evade immune responses. Curr Opin Biotechnol 60, 99-103.

[12] Wang D, Zhong L, Li M, Li J, Tran K, Ren L, He R, Xie J, Moser RP, Fraser C, Kuchel T, Sena-Esteves M, Flotte TR, Aronin N, Gao G (2018) Adeno-associated virus neutralizing antibodies in large animals and their impact on brain intraparenchymal gene transfer. Mol Ther Methods Clin Dev 11, 65-72.

[13] Bjorklund T (2018) Repairing the brain: Gene therapy. $J$ Parkinsons Dis 8, S123-S130.

[14] Ogden PJ, Kelsic ED, Sinai S, Church GM (2019) Comprehensive AAV capsid fitness landscape reveals a viral gene and enables machine-guided design. Science 366, 11391143. 
[15] Negrini M, Wang G, Heuer A, Bjorklund T, Davidsson M (2020) AAV production everywhere: A simple, fast, and reliable protocol for in-house AAV vector production based on chloroform extraction. Curr Protoc Neurosci 93, e103.

[16] Davidsson M, Wang G, Aldrin-Kirk P, Cardoso T, Nolbrant S, Hartnor M, Mudannayake J, Parmar M, Bjorklund T (2019) A systematic capsid evolution approach performed in vivo for the design of AAV vectors with tailored properties and tropism. Proc Natl Acad Sci U S A 116, 27053-27062.

[17] Deverman BE, Pravdo PL, Simpson BP, Kumar SR, Chan KY, Banerjee A, Wu WL, Yang B, Huber N, Pasca SP, Gradinaru V (2016) Cre-dependent selection yields AAV variants for widespread gene transfer to the adult brain. Nat Biotechnol 34, 204-209.

[18] Tervo DG, Hwang BY, Viswanathan S, Gaj T, Lavzin M, Ritola KD, Lindo S, Michael S, Kuleshova E, Ojala D, Huang CC, Gerfen CR, Schiller J, Dudman JT, Hantman AW, Looger LL, Schaffer DV, Karpova AY (2016) A designer AAV variant permits efficient retrograde access to projection neurons. Neuron 92, 372-382.

[19] Chan KY, Jang MJ, Yoo BB, Greenbaum A, Ravi N, Wu WL, Sanchez-Guardado L, Lois C, Mazmanian SK, Deverman BE, Gradinaru V (2017) Engineered AAVs for efficient noninvasive gene delivery to the central and peripheral nervous systems. Nat Neurosci 20, 1172-1179.

[20] Challis RC, Ravindra Kumar S, Chan KY, Challis C, Beadle K, Jang MJ, Kim HM, Rajendran PS, Tompkins JD, Shivkumar K, Deverman BE, Gradinaru V (2019) Systemic AAV vectors for widespread and targeted gene delivery in rodents. Nat Protoc 14, 379-414.

[21] Huang Q, Chan KY, Tobey IG, Chan YA, Poterba T, Boutros CL, Balazs AB, Daneman R, Bloom JM, Seed C, Deverman BE (2019) Delivering genes across the blood-brain barrier: LY6A, a novel cellular receptor for AAV-PHP.B capsids. PLoS One 14, e0225206.

[22] Liguore WA, Domire JS, Button D, Wang Y, Dufour BD, Srinivasan S, McBride JL (2019) AAV-PHP.B administration results in a differential pattern of CNS biodistribution in non-human primates compared with mice. Mol Ther 27, 2018-2037.

[23] Chatterjee D, Marmion DJ, McBride JL, Manfredsson FP, Butler D, Messer A, Kordower JH (2021) Enhanced CNS transduction from AAV.PHP.eB infusion into the cisterna magna of older adult rats compared to AAV9. Gene Ther, doi: 10.1038/s41434-021-00244-y

[24] Flytzanis NC, Goeden N, Goertsen D, Cummins A, Pickel J, Gradinaru V (2020) Broad gene expression throughout the mouse and marmoset brain after intravenous delivery of engineered AAV capsids. bioRxiv, doi: 10.1101/2020.06.16. 152975

[25] Ravindra Kumar S, Miles TF, Chen X, Brown D, Dobreva T, Huang Q, Ding X, Luo Y, Einarsson PH, Greenbaum A, Jang MJ, Deverman BE, Gradinaru V (2020) Multiplexed Cre-dependent selection yields systemic AAVs for targeting distinct brain cell types. Nat Methods 17, 541-550.

[26] Hanlon KS, Meltzer JC, Buzhdygan T, Cheng MJ, SenaEsteves M, Bennett RE, Sullivan TP, Razmpour R, Gong Y, Ng C, Nammour J, Maiz D, Dujardin S, Ramirez SH, Hudry E, Maguire CA (2019) Selection of an efficient AAV vector for robust CNS transgene expression. Mol Ther Methods Clin Dev 15, 320-332.

[27] Nonnenmacher M, Wang W, Child MA, Ren XQ, Huang C, Ren AZ, Tocci J, Chen Q, Bittner K, Tyson K, Pande N, Chung CH, Paul SM, Hou J (2021) Rapid evolution of blood-brain-barrier-penetrating AAV capsids by
RNA-driven biopanning. Mol Ther Methods Clin Dev 20, 366-378.

[28] Ojala DS, Sun S, Santiago-Ortiz JL, Shapiro MG, Romero PA, Schaffer DV (2018) In vivo selection of a computationally designed SCHEMA AAV library yields a novel variant for infection of adult neural stem cells in the SVZ. Mol Ther 26, 304-319.

[29] Voyager Therapeutics, Voyager Therapeutics' Novel Capsids Demonstrate Robust Delivery Across The Blood Brain Barrier, Widespread CNS Transduction In Non-Human Primates, https://ir.voyagertherapeutics.com/news-releases/ news-release-details/voyager-therapeutics-novel-capsidsdemonstrate-robust-delivery, Accessed 05/21.

[30] Davidsson M, Diaz-Fernandez P, Torroba M, Schwich OD, Aldrin-Kirk P, Quintino L, Heuer A, Wang G, Lundberg C, Bjorklund T (2018) Molecular barcoding of viral vectors enables mapping and optimization of mRNA trans-splicing. RNA 24, 673-687.

[31] Davidsson M, Diaz-Fernandez P, Schwich OD, Torroba M, Wang G, Bjorklund T (2016) A novel process of viral vector barcoding and library preparation enables highdiversity library generation and recombination-free pairedend sequencing. Sci Rep 6, 37563.

[32] Hinderer C, Bell P, Katz N, Vite CH, Louboutin JP, Bote E, Yu H, Zhu Y, Casal ML, Bagel J, O'Donnell P, Wang P, Haskins ME, Goode T, Wilson JM (2018) Evaluation of intrathecal routes of administration for adeno-associated viral vectors in large animals. Hum Gene Ther 29, 15-24.

[33] Gray SJ, Matagne V, Bachaboina L, Yadav S, Ojeda SR, Samulski RJ (2011) Preclinical differences of intravascular AAV9 delivery to neurons and glia: A comparative study of adult mice and nonhuman primates. Mol Ther 19, 10581069.

[34] Marques AD, Kummer M, Kondratov O, Banerjee A, Moskalenko O, Zolotukhin S (2021) Applying machine learning to predict viral assembly for adeno-associated virus capsid libraries. Mol Ther Methods Clin Dev 20, 276-286.

[35] Bryant DH, Bashir A, Sinai S, Jain NK, Ogden PJ, Riley PF, Church GM, Colwell LJ, Kelsic ED (2021) Deep diversification of an AAV capsid protein by machine learning. Nat Biotechnol 39, 691-696.

[36] Calcedo R, Vandenberghe LH, Gao G, Lin J, Wilson JM (2009) Worldwide epidemiology of neutralizing antibodies to adeno-associated viruses. J Infect Dis 199, 381-390.

[37] Yu JC, Mietzsch M, Singh A, Jimenez Ybargollin A, Kailasan S, Chipman P, Bhattacharya N, Fakhiri J, Grimm D, Kapoor A, Kucinskaite-Kodze I, Zvirbliene A, Soderlund-Venermo M, McKenna R, Agbandje-McKenna M (2021) Characterization of the GBoV1 capsid and its antibody interactions. Viruses 13, 330.

[38] Havlik LP, Simon KE, Smith JK, Klinc KA, Tse LV, Oh DK, Fanous MM, Meganck RM, Mietzsch M, Kleinschmidt J, Agbandje-McKenna M, Asokan A (2020) Coevolution of adeno-associated virus capsid antigenicity and tropism through a structure-guided approach. $J$ Virol $\mathbf{9 4 ,}$ e00976-20.

[39] Chan YK, Wang SK, Chu CJ, Copland DA, Letizia AJ, Costa Verdera H, Chiang JJ, Sethi M, Wang MK, Neidermyer WJ, Jr., Chan Y, Lim ET, Graveline AR, Sanchez M, Boyd RF, Vihtelic TS, Inciong R, Slain JM, Alphonse PJ, Xue Y, Robinson-McCarthy LR, Tam JM, Jabbar MH, Sahu B, Adeniran JF, Muhuri M, Tai PWL, Xie J, Krause TB, Vernet A, Pezone M, Xiao R, Liu T, Wang W, Kaplan HJ, Gao G, Dick AD, Mingozzi F, McCall MA, Cepko CL, Church GM (2021) Engineering adeno-associated viral vectors to evade 
innate immune and inflammatory responses. Sci Transl Med 13, eabd 3438 .

[40] Rolland AS, Kareva T, Kholodilov N, Burke RE (2017) A quantitative evaluation of a $2.5-\mathrm{kb}$ rat tyrosine hydroxylase promoter to target expression in ventral mesencephalic dopamine neurons in vivo. Neuroscience 346, 126-134.

[41] Mudannayake JM, Mouravlev A, Fong DM, Young D (2016) Transcriptional activity of novel ALDH1L1 promoters in the rat brain following AAV vector-mediated gene transfer. Mol Ther Methods Clin Dev 3, 16075.

[42] Graybuck LT, Daigle TL, Sedeño-Cortés AE, Walker M, Kalmbach B, Lenz GH, Morin E, Nguyen TN, Garren E, Bendrick JL, Kim TK, Zhou T, Mortrud M, Yao S, Siverts LA, Larsen R, Gore BB, Szelenyi ER, Trader C, Balaram P, van Velthoven CTJ, Chiang M, Mich JK, Dee N, Goldy J, Cetin AH, Smith K, Way SW, Esposito L, Yao Z, Gradinaru V, Sunkin SM, Lein E, Levi BP, Ting JT, Zeng H, Tasic B (2021) Enhancer viruses for combinatorial cell-subclassspecific labeling. Neuron 109, 1449-1464.e13.

[43] Blankvoort S, Witter MP, Noonan J, Cotney J, Kentros C (2018) Marked diversity of unique cortical enhancers enables neuron-specific tools by enhancer-driven gene expression. Curr Biol 28, 2103-2114 e2105.

[44] Mich JK, Graybuck LT, Hess EE, Mahoney JT, Kojima Y, Ding Y, Somasundaram S, Miller JA, Kalmbach BE, Radaelli C, Gore BB, Weed N, Omstead V, Bishaw Y, Shapovalova NV, Martinez RA, Fong O, Yao S, Mortrud M, Chong P, Loftus L, Bertagnolli D, Goldy J, Casper T, Dee N, Opitz-Araya X, Cetin A, Smith KA, Gwinn RP, Cobbs C, Ko AL, Ojemann JG, Keene CD, Silbergeld DL, Sunkin SM, Gradinaru V, Horwitz GD, Zeng H, Tasic B, Lein ES, Ting JT, Levi BP (2021) Functional enhancer elements drive subclass-selective expression from mouse to primate neocortex. Cell Rep 34, 108754.

[45] Nair RR, Blankvoort S, Lagartos MJ, Kentros C (2020) Enhancer-driven gene expression (EDGE) enables the generation of viral vectors specific to neuronal subtypes. iScience 23, 100888.

[46] Hsu PH, Wei KC, Huang CY, Wen CJ, Yen TC, Liu CL, Lin YT, Chen JC, Shen CR, Liu HL (2013) Noninvasive and targeted gene delivery into the brain using microbubblefacilitated focused ultrasound. PLoS One 8, e57682.

[47] Hynynen K, McDannold N, Vykhodtseva N, Jolesz FA (2001) Noninvasive MR imaging-guided focal opening of the blood-brain barrier in rabbits. Radiology 220, 640-646.

[48] Kuzmin DA, Shutova MV, Johnston NR, Smith OP, Fedorin VV, Kukushkin YS, van der Loo JCM, Johnstone EC (2021) The clinical landscape for AAV gene therapies. Nat Rev Drug Discov 20, 173-174.

[49] Konermann S, Lotfy P, Brideau NJ, Oki J, Shokhirev MN, Hsu PD (2018) Transcriptome engineering with RNAtargeting type VI-D CRISPR effectors. Cell 173, 665-676 e614.

[50] Zhou H, Su J, Hu X, Zhou C, Li H, Chen Z, Xiao Q, Wang B, Wu W, Sun Y, Zhou Y, Tang C, Liu F, Wang L, Feng C, Liu M, Li S, Zhang Y, Xu H, Yao H, Shi L, Yang H (2020) Glia-to-neuron conversion by CRISPR-CasRx alleviates symptoms of neurological disease in mice. Cell 181, 590-603 e516.

[51] Xiong M, Tao Y, Gao Q, Feng B, Yan W, Zhou Y, Kotsonis TA, Yuan T, You Z, Wu Z, Xi J, Haberman A, Graham J, Block J, Zhou W, Chen Y, Zhang SC (2021) Human stem cell-derived neurons repair circuits and restore neural function. Cell Stem Cell 28, 112-126 e116.
[52] Aldrin-Kirk P, Heuer A, Wang G, Mattsson B, Lundblad M, Parmar M, Bjorklund T (2016) DREADD modulation of transplanted DA neurons reveals a novel parkinsonian dyskinesia mechanism mediated by the serotonin 5-HT6 receptor. Neuron 90, 955-968.

[53] Frederiksen HR, Doehn U, Tveden-Nyborg P, Freude KK (2021) Non-immunogenic induced pluripotent stem cells, a promising way forward for allogenic transplantations for neurological disorders. Front Genome Ed 2, 623717.

[54] Stoddard-Bennett T, Reijo Pera R (2019) Treatment of Parkinson's disease through personalized medicine and induced pluripotent stem cells. Cells $\mathbf{8}, 26$.

[55] Benito-Cuesta I, Diez H, Ordonez L, Wandosell F (2017) Assessment of autophagy in neurons and brain tissue. Cells 6, 25.

[56] Rizzi L, Roriz-Cruz M (2018) Sirtuin 1 and Alzheimer's disease: An up-to-date review. Neuropeptides 71, 54-60.

[57] Minhas PS, Latif-Hernandez A, McReynolds MR, Durairaj AS, Wang Q, Rubin A, Joshi AU, He JQ, Gauba E, Liu L, Wang C, Linde M, Sugiura Y, Moon PK, Majeti R, Suematsu M, Mochly-Rosen D, Weissman IL, Longo FM, Rabinowitz JD, Andreasson KI (2021) Restoring metabolism of myeloid cells reverses cognitive decline in ageing. Nature 590, 122-128.

[58] Lu Y, Brommer B, Tian X, Krishnan A, Meer M, Wang C, Vera DL, Zeng Q, Yu D, Bonkowski MS, Yang JH, Zhou S, Hoffmann EM, Karg MM, Schultz MB, Kane AE, Davidsohn N, Korobkina E, Chwalek K, Rajman LA, Church GM, Hochedlinger K, Gladyshev VN, Horvath S, Levine ME, Gregory-Ksander MS, Ksander BR, He Z, Sinclair DA (2020) Reprogramming to recover youthful epigenetic information and restore vision. Nature 588, 124-129.

[59] Lin K, Zhong X, Li L, Ying M, Yang T, Zhang Z, He $\mathrm{X}, \mathrm{Xu} \mathrm{F}$ (2020) AAV9-Retro mediates efficient transduction with axon terminal absorption and blood-brain barrier transportation. Mol Brain 13, 138.

[60] Kanaan NM, Sellnow RC, Boye SL, Coberly B, Bennett A, Agbandje-McKenna M, Sortwell CE, Hauswirth WW, Boye SE, Manfredsson FP (2017) Rationally engineered AAV capsids improve transduction and volumetric spread in the CNS. Mol Ther Nucleic Acids 8, 184-197.

[61] Tordo J, O'Leary C, Antunes A, Palomar N, Aldrin-Kirk P, Basche M, Bennett A, D'Souza Z, Gleitz H, Godwin A, Holley RJ, Parker H, Liao AY, Rouse P, Youshani AS, Dridi L, Martins C, Levade T, Stacey KB, Davis DM, Dyer A, Clement N, Bjorklund T, Ali RR, AgbandjeMcKenna M, Rahim AA, Pshezhetsky A, Waddington SN, Linden RM, Bigger BW, Henckaerts E (2018) A novel adeno-associated virus capsid with enhanced neurotropism corrects a lysosomal transmembrane enzyme deficiency. Brain 141, 2014-2031.

[62] Zhang X, He T, Chai Z, Samulski RJ, Li C (2018) Bloodbrain barrier shuttle peptides enhance AAV transduction in the brain after systemic administration. Biomaterials 176, 71-83.

[63] Bowles DE, McPhee SW, Li C, Gray SJ, Samulski JJ, Camp AS, Li J, Wang B, Monahan PE, Rabinowitz JE, Grieger JC, Govindasamy L, Agbandje-McKenna M, Xiao X, Samulski RJ (2012) Phase 1 gene therapy for Duchenne muscular dystrophy using a translational optimized AAV vector. $\mathrm{Mol}$ Ther 20, 443-455.

[64] Grimm D, Lee JS, Wang L, Desai T, Akache B, Storm TA, Kay MA (2008) In vitro and in vivo gene therapy vector evolution via multispecies interbreeding and retargeting of adeno-associated viruses. $J$ Virol 82, 5887-5911. 
[65] Choudhury SR, Fitzpatrick Z, Harris AF, Maitland SA, Ferreira JS, Zhang Y, Ma S, Sharma RB, Gray-Edwards HL, Johnson JA, Johnson AK, Alonso LC, Punzo C, Wagner KR, Maguire CA, Kotin RM, Martin DR, Sena-Esteves M (2016) In vivo selection yields AAV-B1 capsid for central nervous system and muscle gene therapy. Mol Ther 24, 1247-1257.
[66] Choudhury SR, Harris AF, Cabral DJ, Keeler AM, Sapp E, Ferreira JS, Gray-Edwards HL, Johnson JA, Johnson AK, Su Q, Stoica L, DiFiglia M, Aronin N, Martin DR, Gao G, Sena-Esteves M (2016) Widespread central nervous system gene transfer and silencing after systemic delivery of novel AAV-AS vector. Mol Ther 24, 726-735. 